\title{
Desain Sistem Enterprise Resource Planning untuk Peningkatan Efektifitas Layanan Umat Gereja
}

\author{
Design of Enterprise Resource Planning Systems for Improving the \\ Effectiveness of Church Services
}

\author{
Astrid Lestari Tungadi ${ }^{*}$, Elisabeth ${ }^{2}$ \\ 1,2) Program Studi Sistem Informasi, Fakultas Teknologi Informasi \\ Universitas Atma Jaya Makassar \\ Jalan Tanjung Alang No. 23, Makassar, Sulawesi Selatan 90134. Telp. (0411) 871038 \\ *e-mail : astrid_tungadi@lecturer.uajm.ac.id
}

\begin{abstract}
ABSTRAK
Penerapan teknologi informasi juga telah banyak digunakan pada

Histori Artikel:

Diajukan:

$19 / 10 / 2018$

Diterima:

$26 / 10 / 2018$

Diterbitkan:

$17 / 11 / 2018$ Surga (GKSPMDkS) merupakan salah satu Gereja Katolik di kota Makassar. Seluruh kegiatan layanan umat masih bersifat manual sehingga pelayanan kepada umat, seperti pendataan data umat, permintaan surat keterangan, dan layanan lainnya berjalan lambat dan belum tertata dengan baik. Sumber daya manusia yang dimiliki oleh gereja sangat minim dibandingkan dengan jumlah umat. Pengambilan keputusan yang berhubungan dengan pelayanan kepada umat terkadang terjadi miss komunikasi antara Pastor Paroki dan anggota Dewan Pastoral sehingga dibutuhkan adanya pemanfaataan teknologi informasi untuk membantu proses pelayanan kepada umat, salah satunya dengan enterprise resource planning (ERP). ERP merupakan suatu cara untuk mengelola sumber daya perusahaan dengan menggunakan teknologi informasi. GKSPMDkS merupakan salah satu contoh organisasi bisnis yang berorientasi non-profit. Dengan adanya sistem ERP pada gereja diharapkan dapat meningkatkan efektifitas layanan umat dan mengintegrasikan komunikasi antar umat dan pihak gereja. Komponen yang dimiliki dalam sistem ERP di GKSPMDkS adalah komponen Finansial, Inventory, Layanan Umat (Service), Proses Pelayanan, Pengelolaan SDM, Distribusi Informasi, dan Penjualan Benda Rohani. Seluruh komponen tersebut diintegrasikan untuk meningkatkan efektifitas pelayanan umat dengan memaksimalkan penggunaan TIK yang dimiliki. Hasil penentuan prioritas pengembangan sistem ERP di GKSPMDkS menggunakan metode AHP menunjukkan komponen sistem layanan umat (service) menjadi komponen yang paling prioritas untuk dikembangkan. Hasil perancangan sub sistem pendataan umat diharapkan menjadi backbone untuk pengembangan sistem ERP di masa yang akan datang.
\end{abstract}

Kata Kunci : Organisasi Non-Profit, Enterprise Resource Planning, Layanan Gereja

\section{ABSTRACT}

The use of information technology has been applied to both profit-oriented and non-profit organizations, such as church organizations. Gereja Katolik Santa Perawan Maria Diangkat ke Surga (GKSPMDkS) is one of the Catholic Churches in the city of Makassar where all service activities are still manual so that services to the people, such as data collection, requests for certificates, and other services are slow and not well organized. Human resources owned by the church are very minimal compared to the number of people. Decision-making related to service to people sometimes miss communication between Pastor Parish and Pastoral Council members so that the use of information technology is needed to help the service process to the people, one of them is enterprise resource planning (ERP). ERP is an approach to managing company resources using information technology. GKSPMDkS is one 
example of a non-profit oriented business organization. With the ERP system in the church, it is hoped that it can improve the effectiveness of community services and integrate communication between people and the church. Based on the results of the research, the components in the ERP system in GKSPMDkS are components of Financial, Inventory, Service, Service Process, HR Management, Information Distribution, and Sales of Spiritual Objects. All of these components are integrated to improve the effectiveness of people's services by maximizing the use of ICTs. The determination of the priority of ERP system development in GKSPMDkS using the AHP method shows that the service system component (service) is the most priority component to be developed. The results of designing the community data collection sub-system are expected to be the backbone for the development of ERP systems in the future.

Keywords : Non-Profit Organization, Enterprise Resource Planning, Church Service

\section{PENDAHULUAN}

Penggunaan teknologi informasi mengalami kemajuan dan perkembangan yang sangat pesat saat ini. Hal tersebut memberikan dampak dan pengaruh terhadap kehidupan manusia. Hal ini dipercaya bahwa dengan mengadopsi teknologi informasi akan dapat membantu perguruan tinggi dalam meningkatkan efektifitas dan efisiensi proses bisnis yang sedang berjalan (Prabowo dan Saintika, 2018). Penerapan teknologi informasi juga telah banyak digunakan pada organisasi, baik yang berorientasi pada profit maupun nonprofit, seperti pada organisasi gereja (Andryanto et al, 2013).

Gereja Katolik Santa Perawan Maria Diangkat ke Surga (GKSPMDkS) merupakan salah satu Gereja Katolik di kota Makassar. Seluruh kegiatan layanan umat masih bersifat manual sehingga pelayanan kepada umat, seperti pendataan data umat, permintaan surat keterangan, dan layanan lainnya berjalan lambat dan belum tertata dengan baik. Sumber daya manusia yang dimiliki oleh gereja sangat minim dibandingkan dengan jumlah umat, sekitar 1500 umat, seperti hanya 1 (satu) Pastor Paroki dan 1 (satu) staf sekretariat. Hal ini berdampak SDM dalam gereja kesulitan untuk melayani dan penyampaian informasi kepada seluruh umat.

Dalam melayani umat, gereja dibantu oleh beberapa Seksi dalam Dewan Pastoral. Umat yang menjadi anggota Dewan Pastoral pada dasarnya memiliki kesibukan lainnya sehingga tidak hanya berfokus pada pelayanan umat. Hal ini berdampak pada komunikasi dan pemberian layanan kepada umat menjadi lambat. Anggota Dewan Pastoral dalam proses pengambilan keputusan untuk hal yang sangat penting dan mendesak yang dialami oleh umat terkadang membutuhkan persetujuan dari Pastor Paroki. Hal ini dapat menyebabkan terjadinya miss komunikasi antara Pastor Paroki, anggota Dewan Pastoral, dan umat karena lambatnya pengambilan keputusan.
Berdasarkan permasalahan ini maka dibutuhkan adanya pemanfaataan teknologi informasi untuk membantu proses pelayanan kepada umat, salah satunya dengan Enterprise Resource Planning (ERP).

Sistem ERP adalah perangkat lunak yang mengintegrasikan, mengatur, mengelola, dan mengotomatisasi sebagian besar proses organisasi bisnis. Sistem ERP yang khas berbagi data berorientasi transaksi dan menerapkan peraturan bisnis standar di berbagai bidang fungsional perusahaan termasuk manufaktur, akuntansi, keuangan, pemasaran, penjualan, sumber daya manusia, dan logistik (Ruhi dan Ghatrenabi, 2015). ERP merupakan suatu cara untuk mengelola sumber daya perusahaan dengan menggunakan teknologi informasi. Penggunaan ERP yang dilengkapi dengan hardware dan software untuk mengkoordinasi dan mengintegrasikan data informasi pada setiap area proses bisnis untuk menghasilkan pengambilan keputusan yang cepat karena menyediakan analisa dan laporan keuangan yang cepat, laporan penjualan yang tepat waktu, laporan produksi, dan inventori (Yasin, 2013).

Tujuan utama mengadopsi sistem ERP adalah untuk menyelesaikan masalah disintegrasi informasi yang berarti informasi berada di lokasi yang berbeda dalam sebuah organisasi. Sistem ini menyediakan perangkat lunak yang mencakup kegiatan di semua departemen dalam sebuah organisasi. Perangkat lunak tersebut mencakup area seperti keuangan, penjualan, layanan pelanggan, dan manajemen sumber daya manusia. Sistem ini dapat diterapkan di berbagai sektor termasuk keuangan, telekomunikasi, perhotelan, pariwisata, dan pendidikan (Bajahzar, 2012).

Saat ini telah banyak penelitian mengenai sistem ERP pada organisasi bisnis yang berorientasi pada profit, baik yang menghasilkan produk (Ernita dan Kusuma, 2008) (David et al, 2013) maupun jasa (Zornada 
dan Velkavrh, 2005). Sistem ERP juga diterapkan pada organisasi bisnis yang berorientasi non-profit, seperti gereja juga telah pernah diteliti sebelumnya (Andryanto et al, 2013).

$$
\text { Ernita dan Kusuma (2008) }
$$

mengembangkan sebuah e-commerce yang menyesuaikan pada konsep ERP pada perusahaan ritel. Sistem yang dikembangkan pada penelitian tersebut bermanfaat bagi perusahan ritel dalam mengelola informasi dalam perusahaan, terutama pada lingkungan ritel yang mengalami perubahan yang sangat cepat.

David et al (2013) melakukan analisa dan sistem pada Usaha Kecil dan Menengah (UKM). Pada penelitian tersebut hanya memfokuskan pada bagian penjualan. Rancangan sistem ERP yang dihasilkan dalam bentuk Use Case Diagram, Class Diagram, Entity Relationship Diagram, dan Architectural Deployment Diagram, bertujuan membuat UKM dapat berjalan secara lebih efisien. Pengolahan data dan integrasi informasi pada rancangan sistem meliputi data master, aktivitas prapenjualan (inquiry dan quotation), aktivitas penjualan (sales order) hingga data dan informasi pembayaran.

$$
\text { Zornada dan Velkavrh (2005) }
$$
melakukan perbandingan mengenai penerapan ERP pada universitas di Slovenia dan luar Slovenia. Pada penelitian tersebut dapat diperoleh bahwa ERP pada universitas telah mencakup sebagian besar aktivitas dalam universitas, seperti aktivitas bisnis, pendidikan, penelitian, sumber daya manusia, administrasi pendukung proses pendidikan, dan administrasi pendukung proses penelitian. Hal ini menunjukkan bahwa sistem ERP dapat diterapkan pada organisasi yang mengelola jasa dan mencakup sebagian besar aktivitas universitas.

Andryanto et al (2013) meneliti mengenai implementasi kelayakan aplikasi ERP Adempiere dalam mendukun sistem administrasi gereja. Hasil penelitian tersebut menunjukkan bahwa aplikasi ERP Adempiere dapat dimanfaatkan untuk mengelola administrasi gereja. Penerapan aplikasi tersebut berdampak pada pengolahan data menjadi lebih mudah dan lebih efisien dibandingkan dengan sistem manual. Manfaat lainnya adalah adanya integrasi informasi antara bagian administrasi dan majelis gereja.

ERP dapat disesuaikan untuk memenuhi kebutuhan unik dari organisasi bisnis yang berorientasi non-profit (Riess, 2012). GKSPMDkS merupakan salah satu contoh organisasi bisnis yang berorientasi non-profit. Dengan adanya sistem ERP pada gereja diharapkan dapat meningkatkan efektifitas layanan umat dan mengintegrasikan komunikasi antar umat dan pihak gereja (Pastor, Sekretariat, dan Dewan Pastoral).

Pada penelitian ini dilakukan analisis penerapan ERP di GKSPMDkS untuk memperoleh komponen sistem ERP di GKSPMDkS. Sistem ERP merupakan sistem yang kompleks sehingga untuk pengembangannya membutuhkan waktu yang lama dan bertahap sehingga dibutuhkan adanya penentuan prioritas komponen sistem ERP mana yang terlebih dahulu dirancang. Penentuan prioritas komponen sistem ERP dapat menggunakan Analytical Hierarchy Process (AHP). Penggunaan AHP untuk menentukan prioritas pengembangan sistem telah diteliti pada (Tungadi dan Suharjito. 2017) (Tungadi, 2017). Komponen sistem ERP yang menjadi prioritas kemudian didesain untuk menjadi backbone dalam pengembangan komponen sistem ERP yang lain. Sistem ERP yang didesain diharapkan menjadi pendukung proses pelayanan kepada umat sehingga dapat diperoleh kualitas layanan yang lebih baik dan efektif.

\section{Enterprise Resource Planning}

Enterprise Resource Planning (ERP) adalah sistem perusahaan yang meliputi semua fungsi yang terdapat di dalam perusahaan yang didorong oleh beberapa modul software yang terintegrasi untuk mendukung proses bisnis internal perusahaan. Sebagai contoh, software ERP untuk perusahaan manufaktur umumnya dimulai dari memproses data yang masuk, melacak status dari penjualan, inventori, pengiriman barang, dan penagihan barang, serta memperkirakan bahan baku dan kebutuhan sumber daya manusia (O'Brien dan Marakas, 2010). Pada Gambar 1 dapat dilihat 5 komponen utama dari sistem ERP.

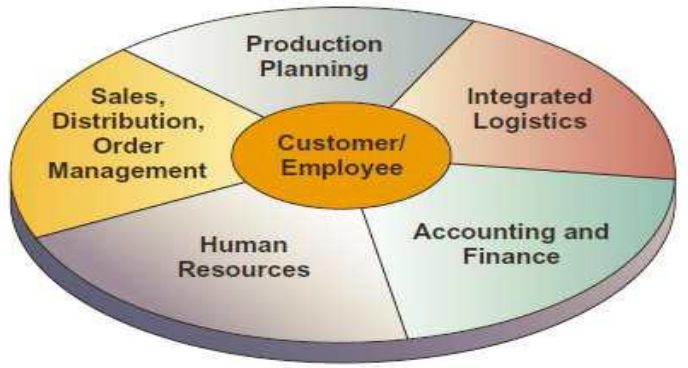

Gambar 1. Komponen Utama ERP (O’Brien dan Marakas, 2010) 
ERP adalah suatu cross-functional atau sistem informasi yang diperuntukkan bagi perusahaan manufaktur maupun jasa guna mengintegrasikan dan mengotomasikan proses bisnis di dalam pabrik, logistik, distribusi, akuntansi, keuangan, dan sumber daya manusia. Implementasi ERP merupakan investasi dan juga tulang punggung perusahaan guna meningkatkan efisiensi kinerja serta mengembangkan bisnis. Pada prinsipnya dengan sistem ERP, sebuah industri atau perusahaan dapat berjalan secara optimal dan dapat mengurangi biaya-biaya operasional yang tidak efisien, seperti biaya inventori maupun biaya kerugian akibat kesalahan teknis (Yasin, 2013).

ERP dapat menghilangkan dinding pemisah antardepartemen dan fungsional dari proses bisnis, sistem informasi, dan sumber daya informasi (Dhewanto dan Falahah, 2007). Sistem ERP mencatat arus sumber daya bisnis (seperti uang, bahan mentah, dan kapasitas produksi), dan status dari perjanjian yang dibuat dalam proses bisnis (seperti pesanan pelanggan, pesanan pembelian, dan gaji pegawai), tidak peduli departemen mana (manufacturing, penjualan, akunting, dan lainnya) yang memasukkan data ke dalam sistem (Rashid et al, 2002). Konsep utama ERP dapat digambarkan pada Gambar 2.

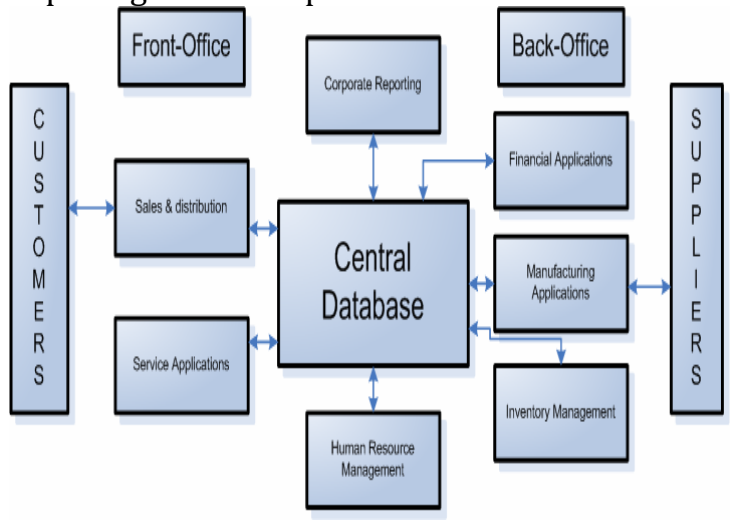

Gambar 2. Konsep dasar ERP (Rashid et al, 2002)

\section{METODE PENELITIAN}

Metode perancangan yang akan digunakan adalah perancangan terstruktur yang memiliki beberapa tahapan seperti terlihat pada Gambar 3. Pada tahapan studi literatur dilakukan pengkajian penelitianpenelitian sebelumnya mengenai rancangan sistem ERP pada organisasi profit secara umum dan organisasi non-profit secara khusus sesuai dengan studi kasus penelitian yaitu Gereja Katolik Santa Perawan Maria Diangkat ke Surga.
Pengumpulan data menggunakan metode observasi, wawancara kepada Pastor Paroki dan Staff Sekretariat, serta penyebaran kuisioner kepada 100 responden umat. Setelah melakukan pengumpulan data, data tersebut diolah, dinilai, dan dianalisis untuk menjelaskan bagaimana tingkat efektifitas pelayanan umat yang saat ini berlangsung di Gereja Katolik Santa Perawan Maria Diangkat ke Surga. Selain itu, analisis data bertujuan untuk memutuskan bagaimana rancangan sistem ERP akan dikembangkan untuk meningkatkan efektifitas pelayanan umat pada Gereja Katolik Santa Perawan Maria Diangkat ke Surga.

Tahapan berikutnya ialah studi kelayakan terhadap rancangan sistem ERP pada Gereja Katolik Santa Perawan Maria Diangkat ke Surga yang dilakukan untuk mengetahui dan menentukan kelayakan perancangan dapat dilakukan atau tidak. Studi kelayakan pada penelitian ini menggunakan faktor TELOS (Teknik, Ekonomi, Legal, Operasional, dan Schedule).

Tahapan selanjutnya ialah desain sistem ERP untuk meningkatkan efektifitas layanan pada Gereja Katolik Santa Perawan Maria Diangkat ke Surga. Desain sistem ERP dirancang dalam bentuk Data Flow Diagram (DFD) untuk memudahkan pemodelan alur sistem yang dirancang. Sebelum dilakukan proses desain sistem ERP, terlebih dahulu ditentukan komponen sistem ERP mana yang akan didesain terlebih dahulu. Penentuan komponen ERP yang menjadi prioritas menggunakan metode Analytic Hierarchy Process (AHP) dengan bantuan tools Expert Choice 11.

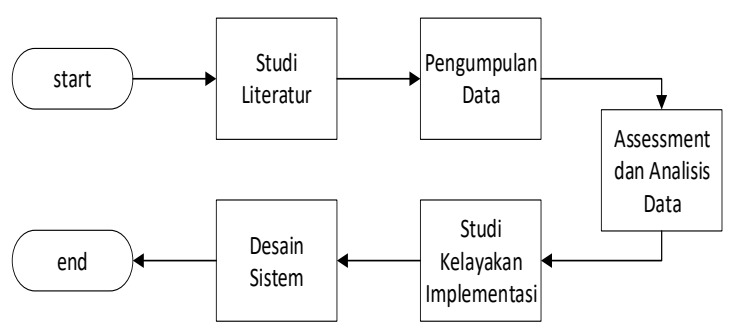

Gambar 3. Metodologi Penelitian

\section{HASIL PENELITIAN DAN PEMBAHASAN}

A. Analisis Efektivitas Layanan Umat Gereja

Untuk mengetahui seberapa efektif layanan umat di GKSPMDkS dilakukan wawancara kepada Pastor Paroki dan Sekretariat Gereja untuk mengetahui kelemahan dari proses layanan yang 
berlangsung saat ini. Selain melakukan proses wawancara, dilakukan pula kuisioner yang melibatkan 100 umat untuk mengetahui respon dari umat terhadap layanan yang diperoleh. Profil umat yang terlibat dalam kuisioner dapat dilihat pada Gambar 4.

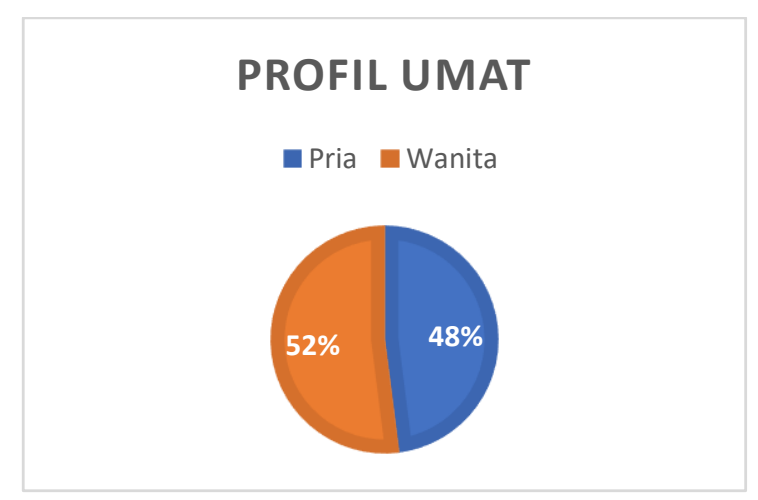

Gambar 4. Profil Peserta Kuisioner Umat

Berdasarkan hasil observasi, kuisioner, dan wawancara terkait efektivitas layanan umat maka dapat diperoleh kesimpulan sebagai berikut:

1. Penyebaran informasi dari gereja ke umat saat ini masih belum dimaksimalkan. Hal ini disebabkan proses distribusi informasi lebih dominan berada di dalam lingkungan gereja melalui Pengumuman Gereja, Berita Gereja, dan papan pengumuman Gereja.

2. Pengurusan pendaftaran sakramen dirasakan belum efektif dikarenakan data umat dicatat secara manual sehingga proses verifikasi membutuhkan waktu yang lama.

3. Proses pembelian barang saat ini dirasakan tidak memiliki kendala karena cukup mudah dan cepat.

\section{B. Analisis Proses Bisnis}

Analisis proses bisnis dilakukan untuk mengetahui proses bisnis GKSPMDkS yang berjalan saat ini. Analisis proses bisnis dilakukan dengan meninjau setiap komponen ERP. Secara garis besar, komponen ERP yang berjalan di GKSPMDkS dapat dilihat pada Gambar 5.

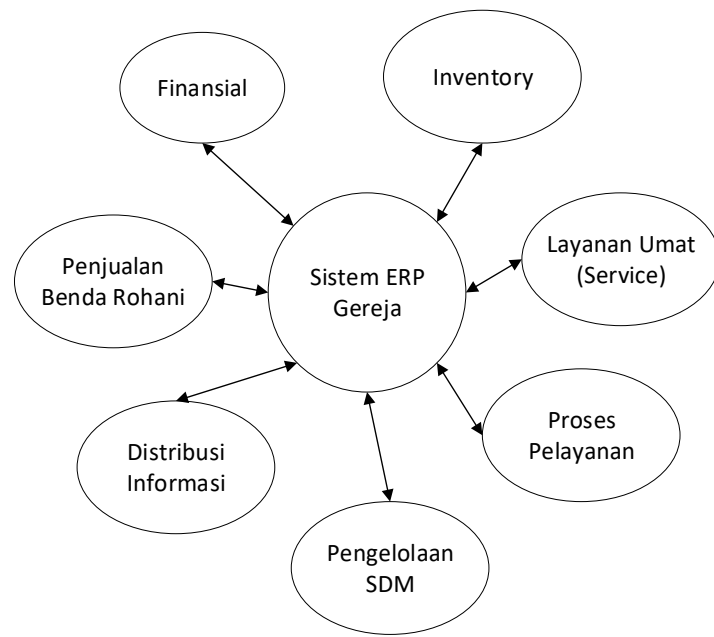

Gambar 5. Komponen Sistem ERP di GKSPMDkS

\section{B.1. Proses Bisnis Finansial}

Pendataan keuangan di GKSPMDkS menggunakan aplikasi Microsoft Excel yang bersifat sederhana saat ini. Pencatatan data keuangan untuk setiap tahun dibuat per file dan per sheet untuk setiap bulan. Format pencatatan bersifat sederhana dengan mencatat bagian debit untuk pemasukan dana serta bagian kredit untuk setiap pengeluaran. Staff Sekretariat Gereja bertanggung jawab dalam melakukan penginputan data finansial gereja dan berada di bawah pengawasan Pastor Paroki.

\section{B.2. Proses Bisnis Inventory}

Pihak yang bertanggung jawab terhadap inventori di GKSPMDkS adalah Seksi Perlengkapan Dewan Pastoral (DEPAS). Seksi ini bertugas untuk melakukan pengecekan dan perbaikan sarana prasana yang dimiliki oleh gereja. Apabila terdapat kerusakan maka terlebih dahulu dilakukan pengecekan terhadap sarana prasana tersebut. Jika dapat diperbaiki maka biaya perbaikan diminta dan dicatat pada file pendanaan gereja. Sarana prasarana yang telah rusak dan tidak dapat diperbaiki akan diganti melalui proses permintaan barang ke donatur maupun pembelian barang baru melalui dana yang dimiliki oleh gereja.

\section{B.3. Proses Bisnis Layanan Umat (Service)}

Pelayanan umat yang sering dilaksanakan adalah pemberian beberapa Sakramen kepada umat. Untuk memperoleh 
Sakramen tersebut, terdapat beberapa syarat dan berkas yang perlu dikumpulkan oleh umat melalui proses pendaftaran. Proses pendaftaran saat ini menggunakan formulir yang harus dilengkapi dengan beberapa dokumen pendukung. Selain itu, Ketua Wilayah berperan untuk membantu umat dalam proses verifikasi formulir pendaftaran Sakramen yang akan diikuti.

\section{B.4. Proses Bisnis Pelayanan Umat}

Proses pelayanan umat secara umum dilakukan oleh Pastor Paroki dan Pastor Kapelan dengan mengikuti permintaan pelayanan dari umat, baik pelayanan di gereja maupun di rumah. Proses permintaan pelayanan umat dapat melalui ketua wilayah maupun oleh umat sendiri. Dalam memberikan pelayanan ibadah di gereja, Pastor Paroki dibantu oleh beberapa Pastor dari Seminari Santo Petrus Claver sebagai pemimpin ibadah. Proses permintaan pelayanan dilakukan oleh Staff Sekretariat Gereja atau Pastor Paroki secara langsung.

Proses pelayanan umat lainnya adalah terkait penjadwalan petugas misa, seperti misdinar, dirigen, organis, lektor, dan pro diakon. Penentuan jadwal petugas misa yang terjadi saat ini masih bersifat manual dimana Ketua Seksi Liturgi Dewan Pastoral bertugas untuk menentukan jadwal petugas misa. Salah satu kendala yang sering ditemui adalah Ketua Seksi Liturgi kesulitan dalam mencari pengganti ketika petugas yang ditunjuk secara tiba-tiba berhalangan dan tidak melaporkannya. Hal ini mengakibatkan terjadinya kekosongan bagian petugas ketika misa berlangsung.

\section{B.5. Proses Bisnis Pengelolaan SDM}

Pengelolaan SDM di GKSPMDkS masih bersifat konvensional karena jumlah SDM yang terlibat sangat minim. Pemberian gaji dilakukan setiap bulan secara merata terhadap Staff Sekretariat Gereja melalui dana gereja. Sedangkan untuk SDM lain, seperti petugas keamanan dan tenaga kebersihan bersifat outsourcing dan menggunakan dana donasi umat. Pada Tabel 1 dapat dilihat jumlah SDM yang terlibat dalam proses bisnis di GKSPMDkS.
Tabel 1. Jumlah SDM di GKSPMDkS

\begin{tabular}{clcc}
\hline No. & Tenaga SDM & Status & Jumlah \\
\hline 1. & $\begin{array}{l}\text { Staff } \\
\text { Sekretariat }\end{array}$ & Tetap & 1 orang \\
2. & $\begin{array}{l}\text { Koster } \\
\text { Gereja }\end{array}$ & Tetap & 2 orang \\
3. & $\begin{array}{l}\text { Petugas } \\
\text { Keamanan }\end{array}$ & Outsourcing & 4 orang \\
4. & $\begin{array}{l}\text { Petugas } \\
\text { Kebersihan }\end{array}$ & Outsourcing & 3 orang \\
\hline
\end{tabular}

\section{B.6. Proses Bisnis Distribusi Informasi}

Proses distribusi informasi terkait gereja dan kebutuhan umat yang dilakukan saat ini menggunakan beberapa sarana media informasi. Sarana media informasi tersebut ada yang bersifat offline maupun online. Sarana media informasi yang bersifat offline memanfaatkan papan pengumuman gereja, pemasangan spanduk, warta berita mingguan gereja, dan penyampaian pengumuman sebelum ibadah dilaksanakan. Sedangkan untuk media informasi online, gereja memiliki website

https://gerejamamajang.wordpress.com.

Website tersebut tidak dilakukan pembaharuan data sehingga umat kesulitan untuk memperoleh informasi terkait gereja secara online.

\section{B.7. Proses Bisnis Penjualan}

Dalam memperoleh dana tambahan untuk gereja dilakukan penjualan benda rohani yang dilaksanakan oleh Koster Gereja. Hasil penjualan benda rohani tersebut dicatat dan dilakukan pembagian hasil dengan Koster Gereja yang menjual.

\section{Studi Kelayakan}

Studi kelayakan dengan faktor TELOS dilakukan untuk mengetahui dan menentukan kelayakan perancangan dapat dilakukan atau tidak. Studi kelayakan dilakukan dengan melakukan wawancara kepada Pastor Paroki dan staff Sekretariat Gereja.

\section{C.1. Kelayakan Teknis}

Penggunaan teknologi informasi dan komunikasi yang digunakan masih sangat minim dimana dapat dilihat jumlah fasilitas yang tersedia sangat minim dalam melayani umat dengan jumlah yang mencapai 1500 umat. Hal ini disebabkan karena seluruh proses bisnis masih berjalan secara manual. Selain itu, 
website yang dimiliki saat ini tidak terkelola dengan baik karena tidak dilakukan pemutakhiran data. Penggunaan fasilitas TIK dapat dilihat Pada Tabel 2.

Tabel 2. Penggunaan Fasilitas TIK

\begin{tabular}{clc}
\hline No. & \multicolumn{1}{c}{ Fasilitas TIK } & Keterangan \\
\hline 1 & Komputer Sekretariat & 1 buah \\
2 & Komputer LCD Misa & 1 buah \\
3 & Printer & 2 buah \\
4 & Laptop Pastor Paroki & 1 buah \\
5 & Internet & $10 \mathrm{Mbps}$ \\
6 & Website & Hosting melalui \\
& & wordpress.com \\
\hline
\end{tabular}

\section{C.2. Kelayakan Ekonomi}

Dari sisi kelayakan ekonomi, GKSPMDkS selama ini mengandalkan donasi dari umat, baik dari donator maupun hasil kolekte untuk operasional sehari-hari. Sejauh ini untuk penggunaan beberapa fasilitas TIK beberapa merupakan sumbangan dari umat dan beberapa fasilitas lainnya merupakan pembelian sendiri.

\section{C.3. Kelayakan Legal}

Dari segi legal, tidak terdapat hukum, baik hukum Gereja maupun hukum negara yang dilanggar terkait perancangan ERP. Perancangan ERP diharapkan dapat membantu dalam meningkatkan pelayanan umat yang berjalan saat ini.

\section{C.4. Kelayakan Operasional}

Tingkat kemampuan Pastor dan staff Sekretariat Gereja dalam menggunakan TIK dapat dikatakan berkualifikasi. Hal ini terlihat dengan penggunaan komputer yang dimiliki saat ini dimanfaatkan dalam menunjang kegiatan operasional sehari-hari, seperti pembuatan surat menyurat, pencatatan data keuangan, dan kegiatan lainnya.

\section{C.5. Kelayakan Schedule (Jadwal)}

Dalam perancangan dan implementasi ERP ke depannya dapat dikatakan layak secara jadwal dikarenakan dari pihak GKSPMDkS memahami untuk memperoleh sistem berbasis TIK membutuhkan waktu yang tidak sedikit dan dibutuhkan adanya perencanaan strategis yang baik.

\section{Penentuan Prioritas Rancangan ERP}

Pada Gambar 4 dapat dilihat bahwa terdapat 7 komponen sistem ERP yang dapat diimplementasikan di GKSPMDkS. Keseluruhan sistem ERP merupakan sistem yang cukup besar dan membutuhkan waktu yang tidak sedikit untuk pengembangan dan implementasi secara keseluruhan dari sistem ERP tersebut. Dikarenakan sistem ERP membutuhkan waktu yang tidak sedikit maka dibutuhkan adanya penentuan prioritas rancangan ERP yang akan dirancang terlebih dahulu.

Penentuan prioritas sistem ERP menggunakan metode Analytic Hierarchy Process (AHP) dengan bantuan tools Expert Choice 11. Kriteria penentuan prioritas dengan mempertimbangkan faktor urgensi, finansial, dampak terhadap umat, dan kompleksitas implementasi komponen. Penentuan bobot melibatkan Pastor Paroki melalui proses wawancara untuk menentukan bobot antar kriteria prioritas. Hasil penentuan prioritas menggunakan tools Expert Choice 11 dengan nilai rata-rata Consistency Ratio sebesar 0.05 dapat dilihat pada Gambar 6.

\section{Synthesis with respect to: Prioritas Rancangan Sistem ERP}

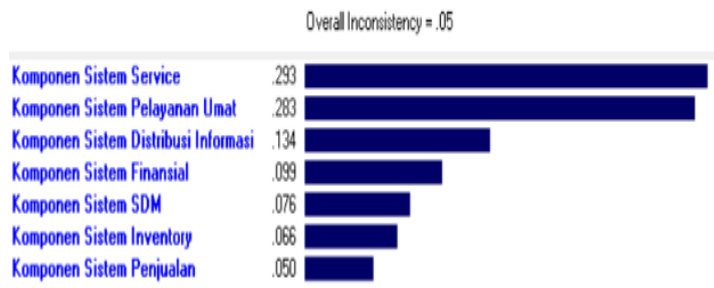

Gambar 6. Prioritas Rancangan Sistem ERP

Pada Gambar 6 dapat dilihat bahwa Komponen Sistem Service merupakan komponen paling penting yang diperlukan untuk dirancang terlebih dahulu. Setelah Komponen Sistem Service, secara berurutan komponen yang menjadi prioritas adalah Komponen Pelayanan Umat, Distribusi Informasi, Finansial, SDM, Inventory, dan Penjualan.

\section{E. Desain Sistem ERP Komponen Layanan Umat (Service)}

Berdasarkan hasil analisis dan penentuan prioritas perancangan (Gambar 5), salah satu permasalahan dalam proses bisnis layanan umat (service) adalah proses pendataan umat yang saat ini masih bersifat manual dimana untuk pencarian data umat, staff Sekretariat Gereja harus membuka buku catatan seluruh data umat. Hal tersebut sangat tidak efisien sehingga dibutuhkan adanya sistem pencatatan umat yang terintegrasi dengan pelayanan apa saja yang dapat diperoleh umat. 
Proses pencatatan data umat yang dirancang hanya melibatkan data umat yang penting, seperti nama, jenis kelamin, tempat dan tanggal lahir, alamat, telepon, rukun/wilayah, nama ayah/ibu, serta status umat saat ini. Selain itu, terdapat fitur untuk pencatatan Sakramen apa yang telah diperoleh oleh umat. Pencatatan Sakramen tersebut dapat berguna untuk proses verifikasi data dalam memperoleh Sakramen lainnya. Sistem pendataan umat ini diharapkan menjadi backbone atau dasar perancangan sistem ERP selanjutnya.

Berdasarkan studi kelayakan teknis, pengguna sistem pendataan umat hanya mencakup 2 (dua) pengguna, yaitu Staff Sekretariat dan Pastor Paroki. Sistem pendataan umat yang dirancang bersifat standalone dikarenakan menyesuaikan sumber daya TIK yang tersedia saat ini.

Rancangan sistem pencatatan umat dapat dilihat pada Gambar 7. Pada Gambar 7 dapat dilihat bahwa staff Sekretariat Gereja bertugas untuk menginput data umat dan data keikutsertaan sakramen umat.

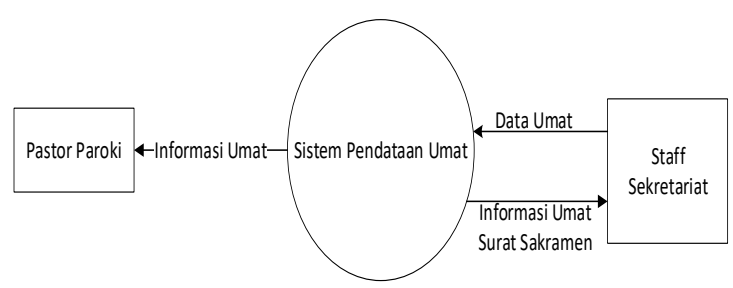

Gambar 7. Alur Kerja Sistem

Data yang telah diinput kemudian menjadi informasi bagi Pastor Paroki dan Staff Sekretariat untuk melihat informasi umat dan verifikasi sakramen apa saja yang telah diikuti oleh umat. Selain itu, sistem juga mengeluarkan Surat Baptis yang akan diberikan pada umat setiap mengikuti sakramen. Struktur database pendataan umat dapat dillihat pada Gambar 8.

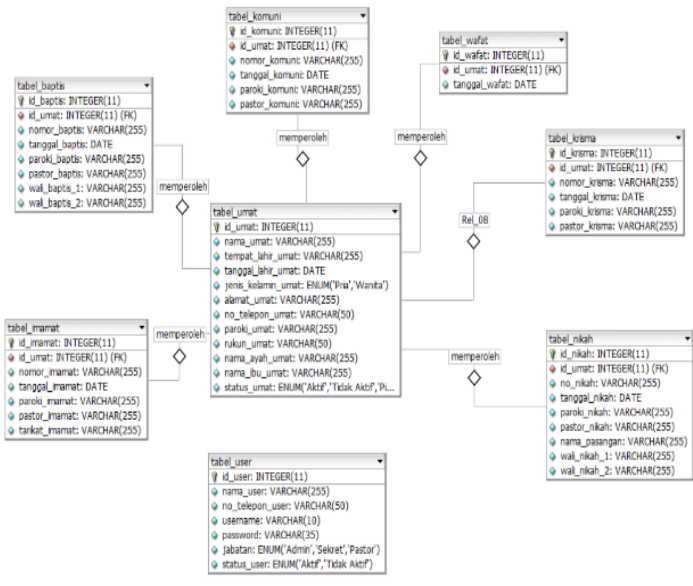

Gambar 8. Struktur Database Pendataan Umat

Pada Gambar 9 dapat dilihat form penginputan data umat. Data umat yang diinput berupa nama, jenis kelamin, tempat dan tanggal lahir, alamat, telepon, rukun/wilayah, nama ayah/ibu, serta status umat saat ini. Data umat yang telah diinput kemudian ditampilkan informasinya dalam daftar umat yang dapat dilihat pada Gambar 9.

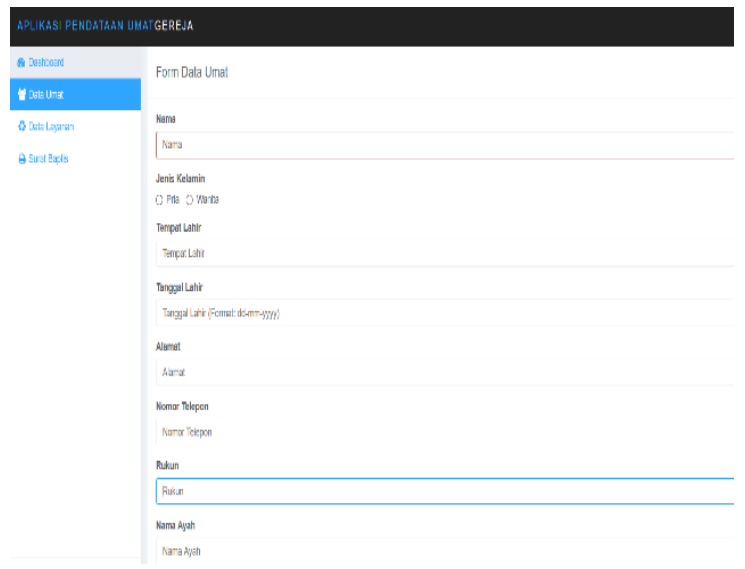

Gambar 9. Tampilan Penginputan Data Umat

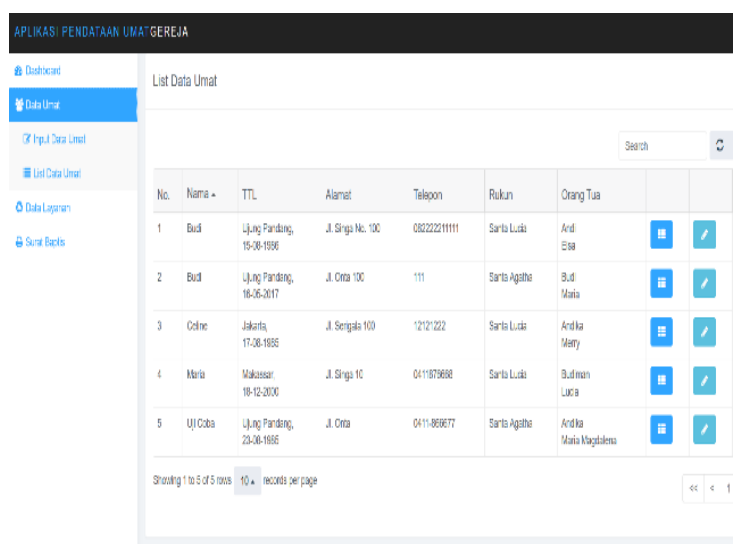

Gambar 10. Tampilan List Data Umat 
Selain penginputan data umat, sistem juga dilengkapi dengan form penginputan data layanan yang terkait sakramen, seperti Sakramen Baptis, Komuni Pertama, Sakramen Krisma, dan Sakramen Pernikahan / Sakramen Imamat. Tampilan form Sakramen Baptis dapat dilihat pada Gambar 11. Setiap penginputan data sakramen memiliki inputan yang berbedabeda sesuai kebutuhan data setiap sakramen.

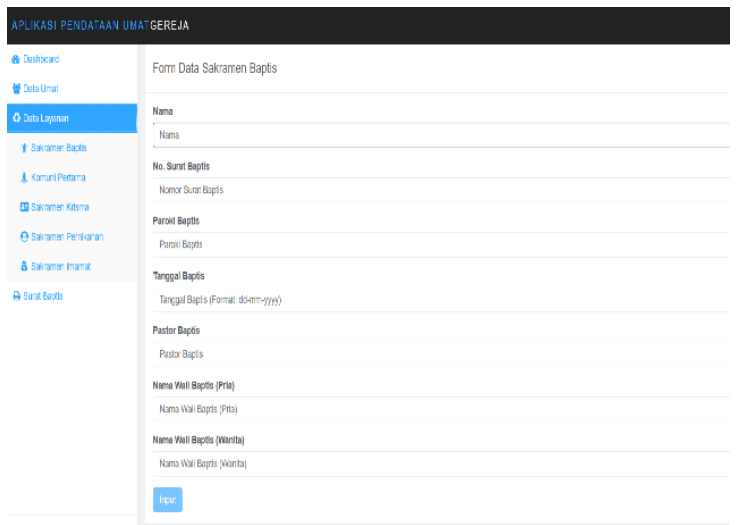

Gambar 11. Tampilan Penginputan Data Sakramen Umat

\section{KESIMPULAN}

Kesimpulan yang dapat diperoleh dari penelitian ini adalah penerapan sistem Enterprise Resource Planning dapat diterapkan pada gereja dengan meninjau dari sisi organisasi non-profit. Berdasarkan hasil pengumpulan data diperoleh 7 komponen sistem ERP di GKSPMDkS, yaitu komponen Finansial, Inventory, Layanan Umat (Service), Proses Pelayanan, Pengelolaan SDM, Distribusi Informasi, dan Penjualan Benda Rohani. Pengembangan seluruh komponen tersebut akan diintegrasikan untuk meningkatkan efektifitas pelayanan umat dengan memaksimalkan penggunaan TIK yang dimiliki. Hasil penentuan skala prioritas pengembangan sistem ERP di GKSPMDkS menggunakan metode AHP berdasarkan studi kelayakan menunjukkan komponen sistem layanan umat (service) menjadi komponen yang paling prioritas untuk dikembangkan. Hasil perancangan sub sistem pendataan umat diharapkan menjadi backbone untuk pengembangan sistem ERP di masa yang akan datang.

Saran yang dapat diberikan dari penelitian ini adalah diperlukan adanya perencaan strategis TI sebagai dasar pengembangan sistem ERP di GKSPMDkS. Selain itu, diperlukan adanya implementasi setiap komponen ERP yang telah dirancang agar dapat diketahui seberapa besar kenaikan tingkat efektifitas pelayanan yang diperoleh.

\section{UCAPAN TERIMA KASIH}

Penulis mengucapkan terima kasih kepada Direktorat Riset dan Pengabdian Masyarakat (DRPM) Kementrian Riset, Teknologi, dan Pendidikan Tinggi atas dukungan yang diberikan kepada penulis berupa bantuan dana penelitian dalam skema Penelitian Dosen Pemula.

\section{DAFTAR PUSTAKA}

Andryanto, A.C., Tambotoh, J., \& Tampake, H.S. (2013). Implementasi Aplikasi Enterprise Resource Planning Adempiere untuk Mendukung Sistem Administrasi Gereja (Studi Kasus: Gereja Pantekosta di Indonesia Siloam Salatiga). Skripsi Universitas Kristen Satya Wacana. Program Studi Sistem Informasi, Fakultas Teknologi Informasi.

Bajahzar, A., Alqahtani, A. \& Baslem, A. (2012). Successful Implementation of Enterprise Resource Planning (ERP). International Conference on Advanced Computer Science Applications and Technologies, pp: 156-160.

David, Ruldeviyani, Y., \& Sandhyaduhita. (2013). Analysis and Design of Enterprise Resource Planning (ERP) System for Small and Medium Enterprises (SMEs) in the Sales Business Function Area. International Conference on Advanced Computer Science and Information Systems (ICACSIS), pp: 255260.

Dhewanto, W., \& Falahah. (2007). ERP (Enterprise Resource Planning). Menyelaraskan Teknologi Informasi dengan Strategi Bisnis. Bandung: Informatika

Ernita, H., \& Kusuma, W. A. (2008). Pengembangan Enterprise Resource Planning (ERP) untuk Perusahaan Ritel. Seminar Nasional Informatika 2008, pp: 149-156.

O'Brien, J.A., \& Marakas, G.M., (2010). Management System Information. New York: McGraw Hill. 
Prabowo, W. A., \& Saintika, Y. (2018). Perancangan IT Balanced Scorecard dalam Penyusunan Strategy Maps Perguruan Tinggi (Studi kasus: Institut Teknologi Telkom Purwokerto). Jurnal Riset Sains dan Teknologi, Vol. 2, No. 1, pp: 27-36.

Rashid, M.A., Hossain, L., \& Patrick, J.D. (2002). The Evolution of ERP System: A Historical Perspective. USA: IRM Press.

Riess, C. J. (2012). Enterprise resource planning for not-for-profits: Aligning people, processes and technology across your organization. McGladrey LLP.

Ruhi, U., \& Ghatrenabi, P. (2015). Experiential Learning Spaces for Enterprise Resource Planning Courses in Business Schools. 2015 Fifth International Conference on $e$ Learning, pp: 316-323.

Tungadi, A. L., \& Suharjito. (2017). Developing IT Strategic Planning using Mobile Enterprise Architecture in the Academic Process of Atma Jaya Makassar University. ComTech: Computer, Mathematics and Engineering Applications, Vol. 8, No. 2, pp: 29-36.

Tungadi, A. L. (2017). Sistem Pendukung Keputusan Penentuan Prioritas Proyek untuk Implementasi IT Strategic Planning Universitas Atma Jaya Makassar. TEMATIKA: Journal of Informatics and Information Systems., Vol. 5, No. 2.

Yasin, V. (2013). Pentingnya Sistem Enterprise Resource Planning (ERP) dalam Rangka untuk Membangun Sumber Data pada Suatu Perusahaan. Jurnal Manajemen Informatika No. 4 Tahun VI, pp: 1-18.

Zornada, L., dan Velkavrh, T.B. (2005). Implementing ERP Systems in Higher Education Institutions. 27th Int. Conf. Information Technology Interfaces ITI 2005, pp: - 